\title{
Katarzyna Wójtowicz
}

Uniwersytet Marii Curie-Skłodowskiej w Lublinie e-mail: kwojtowi@hektor.umcs.lublin.pl

\section{PROBLEM ,ROLOWANIA" \\ DLUGU SAMORZĄDOWEGO I JEGO IMPLIKACJE DLA BEZPIECZEŃSTWA FINANSOWEGO JST}

\section{THE PROBLEM OF ROLLOVER \\ OF SUB-CENTRAL GOVERNMENTS' DEBTS AND ITS CONSEQUENCES FOR FINANCIAL SAFETY OF SUB-CENTRAL GOVERNMENT UNITS}

DOI: $10.15611 /$ pn.2017.485.39

JEL Classification: E62, G28, H74, H76, H81

Streszczenie: Wprowadzenie w 2014 r. nowej reguły fiskalnej limitującej zadłużenie jednostek samorządu terytorialnego miało na celu zahamowanie dynamicznego przyrostu długów samorządowych oraz zmotywowanie do bardziej efektywnego nimi zarządzania. W praktyce jednak wiele samorządów podjęło działania zmierzające do refinansowania swojego zadłużenia, by zdobyć przestrzeń do zaciągania kolejnych zobowiązań. Celem opracowania jest próba określenia skali zjawiska polegającego na „rolowaniu” długów samorządowych oraz wskazanie możliwych jego konsekwencji dla bezpieczeństwa finansowego JST. Głównym wnioskiem płynącym z przeprowadzonych rozważań jest to, że „rolowanie” zadłużenia po roku 2010 stało się powszechne we wszystkich typach JST, i to mimo wyraźnego spadku potrzeb pożyczkowych netto. Powoduje to nadmierne wydłużanie okresów spłaty i znaczący wzrost kosztów finansowania zewnętrznego JST, co może destabilizować finanse samorządowe, prowadząc do niekontrolowanego przyrostu długu w przyszłości.

Słowa kluczowe: dług samorządowy, bezpieczeństwo finansowe, jednostki samorządu terytorialnego.

Summary: The objective of the paper is to determine the scale of the phenomenon of "rollover" of sub-central governments' debts in Poland and an indication of its possible consequences for the financial safety of local government units. The main conclusion is that the "rollover" of local debts has become common practice since 2010. This leads to excessive lengthening maturities and a significant increase in borrowing costs, which can destabilize municipal finances leading to the uncontrolled growth of debt in the future.

Keywords: public debt, financial safety, sub-central governments. 


\section{Wstęp}

Proces kreowania rozwoju lokalnego i regionalnego w Polsce wydaje się niemożliwy bez pozyskiwania zwrotnych źródeł finansowania. Oprócz „konstruktywnego" długu samorządowego, który zwiększa zdolności inwestycyjne JST, zapewnia partycypację kolejnych pokoleń $\mathrm{w}$ finansowaniu infrastruktury i intensyfikuje absorpcję środków unijnych przez samorządy, istnieje także zadłużenie o charakterze „destruktywnym" kreujące nadmierne koszty związanego z jego obsługą, prowadzące do zubożenia społeczności lokalnych i zakłócające realizację zadań samorządowych. Sytuacja ta powoduje konieczność poszukiwania regulacji prawnych, które właściwie określą granice bezpieczeństwa finansowego JST, umożliwiając zarówno utrzymywanie rozmiarów długu publicznego w rozsądnych (bezpiecznych) granicach, jak też sprawną realizację podstawowych funkcji polityki fiskalnej (tj. redystrybucyjnej, alokacyjnej i stabilizacyjnej).

Wprowadzenie nowych ograniczeń fiskalnych, tj. wymogu równowagi operacyjnej oraz tzw. indywidualnego wskaźnika zadłużenia, miało służyć zahamowaniu dynamicznego przyrostu długów samorządowych oraz zmotywowaniu jednostek samorządowych do bardziej efektywnego nimi zarządzania. W praktyce jednak wiele samorządów JST w warunkach napiętej sytuacji budżetowej oraz silnej presji inwestycyjnej podjęło działania zmierzające do „rolowania” (refinansowania) swojego zadłużenia po to, by zdobyć przestrzeń do zaciągania kolejnych zobowiązań.

Celem opracowania jest próba określenia rozmiarów zjawiska polegającego na „rolowaniu” długów samorządowych oraz wskazanie jego następstw dla bezpieczeństwa finansowego JST. Przedmiot badań stanowiły zobowiązania zwrotne zaciągane w latach 2010-2016 przez jednostki samorządu terytorialnego z województwa lubelskiego. Samorządy te charakteryzują się relatywnie dużym zróżnicowaniem w zakresie potencjału finansowego, jak też tempa ich rozwoju, co powoduje, iż są one dość reprezentatywne dla prowadzenia analiz porównawczych oraz formułowania ogólniejszych wniosków.

\section{Istota, przyczyny i zakres „rolowania” długów samorządowych}

W odniesieniu do operacji finansowych, polegających na spłacie „starego” długu za pomocą zaciągania „nowych” zobowiązań finansowych, stosowane są różne określenia, pośród których niekiedy zamiennie używa się terminów takich, jak: refinansowanie, rolowanie, konsolidowanie czy też restrukturyzowanie zadłużenia.

Pomiędzy pojęciami „refinansowanie” i „,rolowanie” stawia się zazwyczaj znak równości, choć zasadniczo refinansowanie długu oznacza jednorazowy wykup, zaś „rolowanie” pewien (powtarzający się) proces ciągłego wykupu zapadających w danym roku zobowiązań finansowych w wyniku zaciągnięcia nowego zadłużenia [Gołębiowski, Marchewka-Bartkowiak (red.) 2015]. Z kolei przedmiotem konsolidacji jest działalność polegająca na scaleniu w jeden tytuł dłużny wielu kredytów i/lub 
pożyczek [Głuchowski (red.) 2001]. Może ona dotyczyć zarówno zobowiązań, które staną się wymagalne w danym roku budżetowym, jak i tych, których termin płatności przypada dopiero w latach następnych. Restrukturyzowanie długu polega natomiast na zmianie jego struktury, m.in. poprzez modyfikację harmonogramu spłat kapitału i odsetek, umorzenie części lub całości wierzytelności czy też obniżenie poziomu oprocentowania [Głuchowski (red.) 2001]. Operacje te mają najczęściej zastosowanie do wierzytelności już przeterminowanych (czy też zobowiązań kredytowych nierokujących szans spłaty) i dokonywane są w efekcie ugody między dłużnikiem a wierzycielem po to, aby uniknąć ponoszenia dalszych strat.

Zdając sobie sprawę z powyższych różnic znaczeniowych i biorąc pod uwagę to, że działania podejmowane przez JST mają bardzo różny charakter i nie zawsze dadzą się przyporządkować do jednej z zaprezentowanych kategorii, na potrzeby niniejszego opracowania przyjęto szerokie rozumienie terminu „rolowanie długów”, który obejmuje swoim zakres wszystkie opisane powyżej sytuacje.

Przechodząc do kwestii przyczyn „rolowania” długów samorządowych, należy zauważyć, że sama operacja polegająca na spłacie dotychczasowego zadłużenia poprzez zaciąganie nowego długu w warunkach dynamicznego rozwoju rynków finansowych jest czymś zupełnie naturalnym, zarówno w przypadku podmiotów z sektora prywatnego, jak i publicznego. Jej przyczyną jest najczęściej chęć utrzymania bądź przywrócenia płynności finansowej w sytuacji braku możliwości wygospodarowania nadwyżek finansowych pochodzących ze środków własnych, rezerw lub innych możliwych do pozyskania źródeł, z których możliwa byłaby spłata długu zaciągniętego w latach poprzednich [Marchewka-Bartkowiak 2012]. W takim przypadku eksponuje się tzw. ryzyko refinansowania, które jest tym większe, im wyższa jest płatność z tytułu wykupu zapadającego długu i im bliższy jest termin jego zapadalności. Do ograniczenia tego ryzyka przyczynia się wydłużenie okresu całkowitego wykupu długu oraz równomierne rozłożenie tych spłat w czasie [Budzeń 2016]. „Rolowanie” długów może także dotyczyć sytuacji, w których płynność finansowa i wypłacalność dłużników nie są wcale zagrożone, lecz dłużnicy dążą do korzystniejszego dostosowania struktury i kosztów zadłużenia do swojej sytuacji ekonomicznej, np. w wyniku zamiany kilku droższych kredytów na jeden tańszy.

W przypadku JST w nowych uwarunkowaniach prawnych określonych w ustawie o finansach publicznych z 2009 r. ([Ustawa z 29 sierpnia 2009] dalej u.o.f.p.) zjawisko „rolowania” długów samorządowych nabrało nieco innego wymiaru.

Po pierwsze, mamy do czynienia z wyraźną intensyfikacją tych działań z apogeum przypadającym na lata 2012-2013. Na rysunku 1 zaprezentowano zakres refinansowania zadłużenia na przykładzie JST województwa lubelskiego w latach 2010-2016. Do oceny rozmiarów tego zjawiska posłużono się różnicą między wartością ogółu zobowiązań zwrotnych (w postaci kredytów oraz wyemitowanych papierów wartościowych) zaciągniętych przez badane samorządy w danym roku budżetowym (odpowiadającą w przybliżeniu pojęciu potrzeb pożyczkowych brutto PPB) a wielkością rzeczywistego przyrostu długu w tym roku w stosunku do roku 
poprzedniego (tj. tzw. potrzeb pożyczkowych netto - PPN) [Jurewicz 2016]. Z danych zawartych na rys. 1 wynika, że „rolowanie” długów wyrażone różnicą między PPB a PPN systematycznie nasilało się w latach 2011-2013, zarówno we wszystkich JST w województwie lubelskim, jak też w ich poszczególnych typach. Po roku 2013 działania te uległy pewnemu osłabieniu, niemniej jednak i tak wartości tej różnicy są wyższe niż w roku 2010, tj. w pierwszym badanym roku budżetowym. Trzeba także dodać, że nasilenie refinansowania długów samorządowych następowało pomimo wyraźnego spadku w tym samym okresie potrzeb pożyczkowych netto, które w przypadku analizowanych jednostek samorządowych zmalały z blisko $146 \mathrm{mln}$ zł w roku 2010 do ok. 92 mln zł w roku 2013.

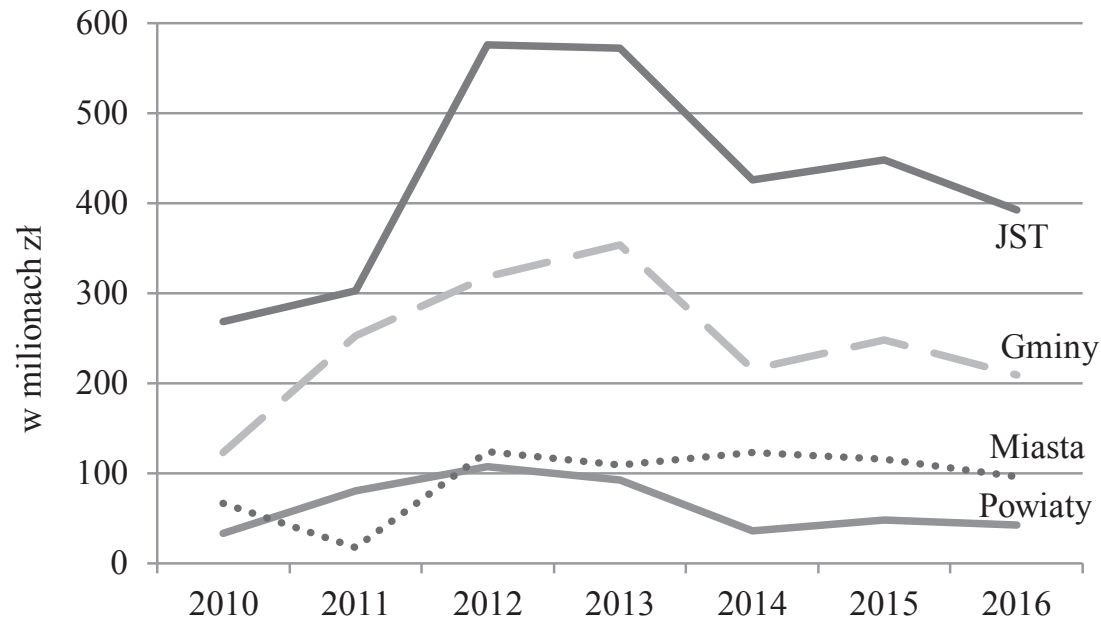

Rys. 1. Skala zjawiska polegającego na ,rolowaniu” zadłużenia (mierzonego jako różnica między potrzebami pożyczkowymi brutto a potrzebami pożyczkowymi netto)

w JST województwa lubelskiego w latach 2010-2016

Źródło: opracowanie własne na podstawie danych pochodzących z rocznych sprawozdań z wykonania budżetów przez JST województwa lubelskiego, dostępnych na stronach internetowych Regionalnej Izby Obrachunkowej w Lublinie (www.bip.lublin.rio.gov.pl).

Po drugie, jednym z głównych celów „rolowania” zadłużenia przez JST stało się wypełnienie nowych reguł fiskalnych (tj. określonego w art. 242 u.o.f.p. wymogu równowagi operacyjnej oraz wynikającej z art. 243 u.o.f.p. relacji łącznej kwoty spłaty zobowiązań wraz z kosztami ich obsługi w stosunku do dochodów budżetowych ogółem, czyli tzw. indywidualnego wskaźnika zadłużenia - IWZ). Jeśli chodzi o nakaz zrównoważenia budżetu JST w jego części bieżącej, to refinansowanie zadłużenia służyło przede wszystkim obniżeniu wydatków na obsługę długu, stanowiących składnik wydatków bieżących. Pewne znaczenie dla zwiększenia analizowanej powyżej różnicy między PPB a PPN miało także dopuszczenie do bilanso- 
wania salda operacyjnego za pomocą tzw. wolnych środków ${ }^{1}$. Prowadziło to bowiem do zaciągania (niekiedy zbędnych z ekonomicznego punktu widzenia) zobowiązań dłużnych na pokrycie „sztucznie” wykreowanych planowanych deficytów budżetowych, które w praktyce pod koniec roku zazwyczaj okazywały się dużo niższe, co umożliwiało skumulowanie wolnych środków i zrównoważenie budżetu bieżącego [KR RIO 2016]. Z kolei w przypadku IWZ ,rolowanie długu” służyło zamianie „starych” długów o wysokiej racie kapitałowe i odsetkowej na „,nowe” długi o zmodyfikowanych warunkach i harmonogramie ostatecznej spłaty, co pozwalało na obniżenie wysokości ponoszonych w poszczególnych latach budżetowych obciążeń finansowych związanych z zadłużeniem i tym samym wypełnienie relacji zawartej w art. 243 u.o.f.p.

Po trzecie, nasilenie skali refinansowania długów samorządowych jest wyrazem szerszej tendencji opisywanej w raportach Krajowej Rady Regionalnych Izb Obrachunkowych [KR RIO 2014; 2016] oraz Najwyższej Izby Kontroli [NIK 2015; 2016], polegającej na swoistym „wypychaniu” zadłużenia JST poza obszar standardowych operacji finansowych o charakterze przychodowo-rozchodowym. Chodzi tu zwłaszcza o stosowanie tzw. inżynierii finansowej w postaci zawierania przez samorządy różnego typu umów (w tym m.in. umów nienazwanych, takich jak: sekurytyzacja, forfaiting, factoring, cesja wierzytelności, oraz umów nazwanych, takich jak: sprzedaż zwrotna, leasing zwrotny itd.) o konsekwencjach ekonomicznych zbliżonych do klasycznych kredytów czy pożyczek, natomiast ze względu na specyficzną konstrukcję prawną niewykazywanych w ewidencji księgowej i sprawozdawczości JST jako zadłużenie i niepodlegających w związku z tym limitacji. Operacje te są bardzo często określane mianem „długu ukrytego”, a sposobność do ich zaciągania stwarza stosunkowo wąsko zarysowany katalog tytułów dłużnych ${ }^{2}$, poza którymi JST poszukują sposobu na obejście obowiązujących reguł fiskalnych [Langer 2014].

Po czwarte, do „rolowania” zadłużenia przez JST przyczyniła się także wzmożona promocja banków i instytucji finansowych oferujących szeroką gamę produktów dłużnych (takich jak np. subrogacja ${ }^{3}$ ) dostosowanych do potrzeb poszczególnych

\footnotetext{
${ }^{1}$ Wolne środki w szerokim tego słowa znaczeniu oznaczają środki finansowe, które nie są wydatkowane na realizację określonych zadań JST. Przez wolne środki sensu stricto rozumieć należy natomiast nadwyżkę środków pieniężnych na rachunku bieżącym budżetu JST, wynikającą z rozliczeń wyemitowanych papierów wartościowych, kredytów i pożyczek z lat ubiegłych. W dużym uproszczeniu przyjąć można, że jest to różnica między przychodami a rozchodami budżetowymi. Tak rozumiane wolne środki w ujęciu wąskim mogą stanowić instrument równoważenia budżetu operacyjnego [Woźniak 2014].

${ }^{2}$ Określony w art. 72, ust. 2 u.o.f.p. oraz w Rozporządzeniu Ministra Finansów z 28 grudnia 2011 r. w sprawie szczegółowego sposobu klasyfikacji tytułów dłużnych zaliczanych do państwowego długu publicznego (Dz.U. nr 298, poz. 1767).

${ }^{3} \mathrm{Na}$ mocy Kodeksu cywilnego (art. 518 ustawy z dnia 23 kwietnia 1964 r. - Kodeks cywilny) subrogacja polega na tym, że osoba trzecia, która spłaca wierzyciela, nabywa spłaconą wierzytelność do wysokości dokonanej zapłaty. Może to nastąpić w trzech sytuacjach, tzn. po pierwsze, jeżeli płaci cudzy dług, za który jest odpowiedzialna osobiście albo pewnymi przedmiotami majątkowymi; po dru-
} 
jednostek samorządowych. Warto w tym miejscu zauważyć, że instrumenty te były bardzo często reklamowane jako rozwiązania niepodlegające reżimowi finansów publicznych, jak również jako polecane czy wręcz rekomendowane przez organy nadzoru, co zazwyczaj okazywało się nieprawdą ${ }^{4}$.

\section{Uwarunkowania prawne refinansowania długów samorządowych}

Podstawą prawną refinansowania długów samorządowych jest art. 89, ust. 1, pkt 3 u.o.f.p. określający wśród przeznaczenia środków pieniężnych pochodzących z zaciąganych przez JST kredytów lub pożyczek oraz wyemitowanych obligacji m.in. spłatę wcześniej zaciągniętych zobowiązań z tego tytułu.

Niemniej jednak w praktyce problem ,rolowania” długów samorządowych nie jest jednolicie interpretowany i w związku z tym organy nadzoru wydają odmienne opinie przy badaniu uchwał $\mathrm{w}$ sprawie spłaty dotychczasowego długu, podejmowanych na podstawie przywołanego powyżej przepisu prawnego.

Rozbieżności w orzecznictwie regionalnych izb obrachunkowych dotyczą zasadniczo dwóch kwestii, tj.

1. zakresu odzwierciedlenia w budżecie samorządowym konsekwencji finansowych działań polegających na pozyskiwaniu zwrotnych środków pieniężnych o charakterze długoterminowym oraz ich wykorzystaniu na spłatę wcześniej zaciągniętych kredytów i pożyczek,

2. skali wpływu tych operacji (w roku ich wykonania) na przestrzeganie relacji określonej przez IWZ.

W związku z powyższym wyodrębnić można dwa główne stanowiska organów nadzoru odnoszące się do omówionych kwestii.

Pierwsze z nich wyraża się w traktowaniu działań związanych z zaciąganiem „nowego" długu oraz spłatą „starego" długu jako pozabudżetowych operacji finansowych, które nie muszą mieć odzwierciedlenia po stronie przychodowej oraz roz-

gie, jeżeli przysługuje jej prawo, przed którym spłacona wierzytelność ma pierwszeństwo zaspokojenia, i po trzecie, jeżeli działa za zgodą dłużnika w celu wstąpienia w prawa wierzyciela; zgoda dłużnika powinna być pod nieważnością wyrażona na piśmie; a także w innych przypadkach, jeśli przewidują to przepisy szczególne. Konstrukcje prawne stosowane w praktyce samorządowej nie stanowią jednak typowej subrogacji, bowiem celem instytucji finansowej nabywającej wierzytelność od JST nie jest wejście w prawa wierzyciela, ale stworzenie nowego stosunku prawnego, który z ekonomicznego punktu widzenia ma cechy tożsame z otrzymaniem przez samorząd kredytu na zaspokojenie określonego dotychczasowego wierzyciela (przy czym spłata zobowiązania będzie ujmowana w budżecie jako wydatek). Szczególnym rodzajem takiej operacji jest porozumienie w sprawie restrukturyzacji długu poprzez udostępnienie samorządowi środków finansowych przez instytucję finansującą na spłatę zobowiązań [KR RIO 2016].

${ }^{4}$ Jako przykład można tu wskazać ofertę jednego z banków, który promując różne metody poprawy struktury zobowiązań przez JST, wskazywał, że konsolidacja zadłużenia oraz subrogacja są rozwiązaniami zalecanymi przez regionalne izby obrachunkowe [KR RIO 2016]. 
chodowej budżetu w roku ich przeprowadzenia. Konsekwencją praktyczną takiego podejścia jest brak wpływu jednorazowej spłaty wcześniej zaciągniętych zobowiązań na zachowanie relacji określonej w art. 243 u.o.f.p. [Witalec 2014] .

Do głównych argumentów na poparcie takiego stanowiska zalicza się m.in.:

1. brak oddziaływania działań restrukturyzacyjnych na wielkość zadłużenia JST na koniec roku budżetowego w stosunku do jego stanu z początku roku,

2. specyficzną technikę operacyjną przekazywania środków finansowych pochodzących z „,nowego” zadłużenia przez bank udzielający kredytu konsolidacyjnego bezpośrednio na rzecz dotychczasowych wierzycieli poza rachunkiem bankowym służącym do obsługi budżetu JST,

3. podwójne ujmowanie kwoty spłaty „starego” zadłużenia w IZW w roku przeprowadzenia tej operacji, a następnie spłat ,nowego” długu w kolejnych latach budżetowych,

4. to, iż refinansowanie długu uznawane jest za jedyny możliwy sposób na uchwalenie budżetu przez niektóre samorządy w sytuacji niespełniania przez nie relacji określonej przez IWZ (przy czym argument ten stracił rację bytu po nowelizacji u.o.f.p. z roku 2013 wprowadzającej specjalny mechanizm rozwiązywania tego problemu za pomocą programu postępowania naprawczego) ${ }^{6}$.

Drugie przeciwstawne stanowisko organów nadzoru wskazuje natomiast na konieczność pełnego ujmowania w przychodach i rozchodach budżetowych wysokości środków pieniężnych pochodzących z kredytów konsolidacyjnych wykorzystanych na spłatę wcześniejszych zobowiązań o charakterze dłużnym. W efekcie konieczne jest także nieprzekraczanie limitu określonego w art. 243 u.o.f.p zarówno w roku, w którym zaciągnięto „,nowy” dług i spłacono za jego pomocą „stary”, jak i w kolejnych latach, w których odbywa się obsługa tego „nowego” zadłużenia?.

Uzasadnieniem takiego poglądu są następujące okoliczności:

1. art. 91 u.o.f.p., na mocy którego suma zaciągniętych kredytów i pożyczek oraz zobowiązań z wyemitowanych papierów wartościowych nie może przekroczyć kwoty określonej w uchwale budżetowej JST,

2. wymóg przestrzegania zasad jawności i przejrzystości finansów publicznych,

${ }^{5}$ Podejście to ma swoje odzwierciedlenie m.in. w następujących stanowiskach organu nadzoru: RIO w Białymstoku, www.zbojna.powiatlomzynski.pl/bip/zalaczniki/art/130108152715.pdf; RIO w Kielcach, www.bip.gminy.com.pl/gnojno/pliki/6_uchwalariokonsolid.pdf; RIO w Poznaniu, www. bip.poznan.rio.gov.pl/?p=document\&action=save\&id; RIO w Rzeszowie, bip.baligrod. $\mathrm{pl} /$ ?c=mdPliki-cmPobierz-2441; RIO we Wrocławiu, bip.sp-legnica.dolnyslask.pl/dokument.php?iddok=1948\&str=12, cyt. za: [Witalec 2014].

${ }^{6}$ Wprowadzony mocą Ustawy o zmianie ustawy o finansach publicznych oraz niektórych innych ustaw z dnia 8 listopada 2013 r., Dz.U. z 2013, poz. 1646.

${ }^{7}$ Por. stanowiska: RIO w Katowicach, http://www.rio.katowice.bip.net.pl/?p=document\&action=show\&id=1441\&bar_id=2307; RIO w Opolu, www.samorzad.pap.pl/.../rio/.../Finanse-na-progu--Splata-kredytem--konsolidacyjnym-nie-zwalnia-z-limitu-dlugu; RIO w Olsztynie, bip.warmia.mazury.pl/ powiat.../system/.../rio-09082013142553.pdf, cyt. za: [Witalec 2014]. 
3. wpływ operacji związanych z refinansowaniem zadłużenia na zmiany w jego strukturze (np. w sytuacji gdy w efekcie spłaty „starego” długu dochodzi do zamiany instrumentów dłużnych, np. z obligacji na kredyt) oraz na warunki jego spłaty (koszty obsługi, terminy płatności), a w efekcie na stan gospodarki finansowej JST na koniec roku budżetowego,

4. oddziaływanie takich działań na kształt Wieloletniej Prognozy Finansowej, w której ujmuje się nie tylko kwotę długu, ale także przychody, rozchody, oraz wydatki związane z jego obsługą w okresie aż do całkowitej spłaty zadłużenia.

Choć drugie z zaprezentowanych stanowisk wydaje się w zdecydowanie szerszym aspekcie uwzględniać ekonomiczny charakter operacji polegających na ,rolowaniu" zadłużenia, to jednak i w tym przypadku nie wskazano skutecznych dróg wyjścia z sytuacji polegającej na braku możliwości zachowania relacji określonej w art. 243 u.o.f.p. w roku jednorazowej spłaty „starego” długu za pomoca „nowego” zadłużenia. Dlatego też, gdy do takiego przekroczenia dochodziło, organy nadzoru wyciągały zazwyczaj łagodniejsze konsekwencje prawne [Witalec 2014].

\section{Następstwa ekonomiczne refinansowania długów samorządowych}

W świetle rozbieżnych stanowisk organów kontroli i nadzoru w dziedzinie oceny zjawiska „rolowania” długów samorządowych należy zastanowić się nad następstwami ekonomicznymi takich działań, bowiem to właśnie one winny determinować sposób rozwiązania tego problemu.

Wydaje się, że konsekwencje te z uwagi na ich charakter oraz sposób i zasięg oddziaływania można podzielić na dwie grupy, tj. skutki bezpośrednie, będące efektem ustalenia nowych warunków zadłużenia wynikających z zawarcia nowych umów kredytowych (pożyczkowych), oraz następstwa pośrednie, które wynikają z tych pierwszych, jednak są bardziej ogólne, a w dłuższym okresie mogą rzutować na przyszły stan gospodarki finansowej JST.

Do bezpośrednich następstw refinansowania długów samorządowych zaliczyć należy przede wszystkim wydłużanie okresów całkowitej spłaty zadłużenia. W tabeli 1 zaprezentowano procentowy rozkład JST z województwa lubelskiego ze względu na wyrażony w latach termin ostatecznej spłaty długu zaplanowany w Wieloletnich Prognozach Finansowych sporządzonych wraz z budżetami na rok 2011 (WPF 2011+) oraz na rok 2017 (WPF 2017+). Z zestawienia tego wynika, że w latach 2011-2016 zmniejszył się odsetek samorządów, które planowały, że posiadane przez nie zadłużenie zostanie spłacone w okresie do 6 lat (z ponad 42\% w roku 2011 do ok. 31\% na koniec 2016 roku) Natomiast zdecydowanie zwiększył się udział JST, dla których okres całkowitej spłaty długu przekraczać ma 10 lat (w roku 2011 zaplanowało to ok. 21\% samorządów, zaś w 2016 już blisko 30\%).

Bezpośrednią konsekwencją ,rolowania” zadłużenia przez JST stało się także stosowanie coraz dłuższych karencji w spłacie kapitału [Kluza 2013]. Karencje, któ- 
Tabela 1. Procentowy rozkład JST z woj. lubelskiego według okresu całkowitej spłaty długu (na podstawie WPF-ów sporządzanych na rok budżetowy 2011 i 2017)

\begin{tabular}{|l|c|c|}
\hline \multirow{2}{*}{$\begin{array}{c}\text { Okres całkowitej spłaty zadłużenia } \\
\text { (w latach) }\end{array}$} & Procentowy rozkład JST województwa lubelskiego \\
\cline { 2 - 3 } od 4 do 6 & 42,9 & WPF 2017+ \\
\hline od 7 do 10 & 35,9 & 31,3 \\
\hline od 11 do 15 & 15,2 & 39,5 \\
\hline od 16 do 20 & 3,8 & 22,6 \\
\hline od 21 do 25 & 1,1 & 4,1 \\
\hline od 26 do 30 & 0,5 & 1,6 \\
\hline pow. 31 & 0,5 & 0,8 \\
\hline
\end{tabular}

Źródło: opracowanie własne na podstawie bazy danych zawierającej Wieloletnie Prognozy Finansowe jednostek samorządu terytorialnego z województwa lubelskiego, udostępnionych przez Regionalną Izbę Obrachunkową w Lublinie.

re przed rokiem 2010 należały do rzadkości i zasadniczo nie przekraczały jednego roku, w kolejnych latach stały się powszechną praktyką w przetargach na kredyty o charakterze długoterminowym. $Z$ zestawienia sporządzonego na podstawie bazy Biuletynu Zamówień Publicznych dla zamówień ogłaszanych przez JST z województwa lubelskiego na udzielenie i obsługę kredytów konsolidacyjnych w latach 2010-2016 ${ }^{8}$ (por. rys. 2) wynika, że ponad 50\% tych przetargów dotyczyło kredytów z karencją przekraczającą 1 rok (w tym 4\% z karencją sięgającą 5 lat lub więcej). Jak wskazuje Kluza [2013], często stosowanym zabiegiem były ponadto tzw. ukryte karencje polegające na tym, iż formalnie samorząd zobowiązany był od początku do spłat zarówno rat kapitałowych, jak i odsetkowych, przy czym te pierwsze były w początkowym okresie kredytowania ustalane na znikomym poziomie, sięgającym zaledwie kilku złotych.

Kolejnym skutkiem podejmowanych działań stało się również zwiększenie kosztu pozyskiwanego kapitału zewnętrznego. Na rys. 3 przedstawiono średnie oprocentowanie zadłużenia JST z woj. lubelskiego w latach 2011-20169. W celu jego wyznaczenia odniesiono dla każdego roku budżetowego kwotę wydatków bieżących na obsługę długu w tym roku (tj. w roku $n$ ) do pozostającej do spłaty wartości zadłużenia na koniec okresu $n-1$. Jednocześnie dla odzwierciedlenia rynkowej

${ }^{8}$ Wyszukiwanie przeprowadzono dla frazy „kredyt konsolidacyjny”, podmiotem zamawiającym były JST z województwa lubelskiego, zaś data publikacji ogłoszenia obejmowała lata 2010-2016. Pod uwagę wzięto jedynie te przetargi, które zakończyły się pozytywnym rozstrzygnięciem w postaci udzielenia kredytu, co dało rezultat w postaci 62 ogłoszeń. Baza dostępna jest pod adresem: https://bzp. uzp.gov.pl (5 maja 2017).

${ }^{9}$ Niestety, na podstawie obowiązującej sprawozdawczości budżetowej nie było możliwe wyodrębnienie oprocentowania poszczególnych instrumentów dłużnych, a zatem wielkość ta uwzględnia całkowity (wyrażony w \%) koszt finansowania zewnętrznego. 


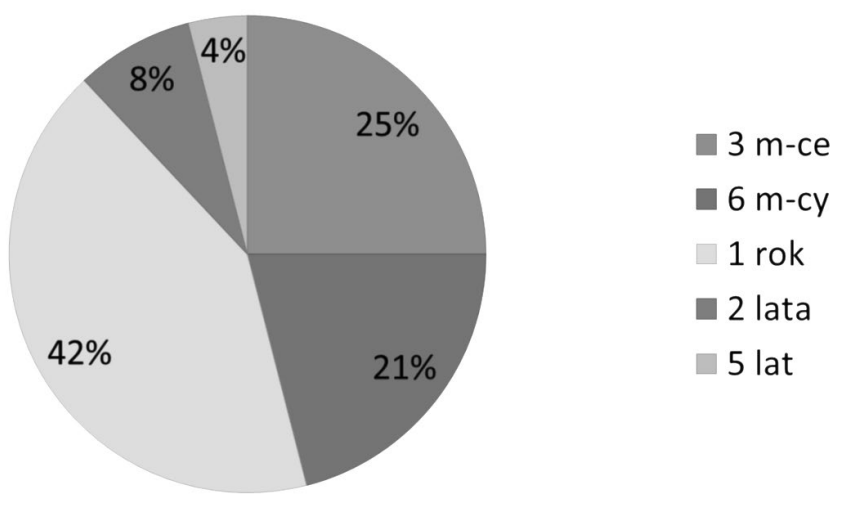

Rys. 2. Procentowy rozkład ogłoszeń o kredyt konsolidacyjny według zakładanej długości karencji w spłacie kapitału (62 ogłoszenia z BZP z lat 2010-2016, zamawiający: JST z woj. lubelskiego)

Źródło: baza ogłoszeń Biuletynu Zamówień Publicznych dostępna pod adresem internetowym https:// bzp.uzp.gov.pl (5 maja 2017).

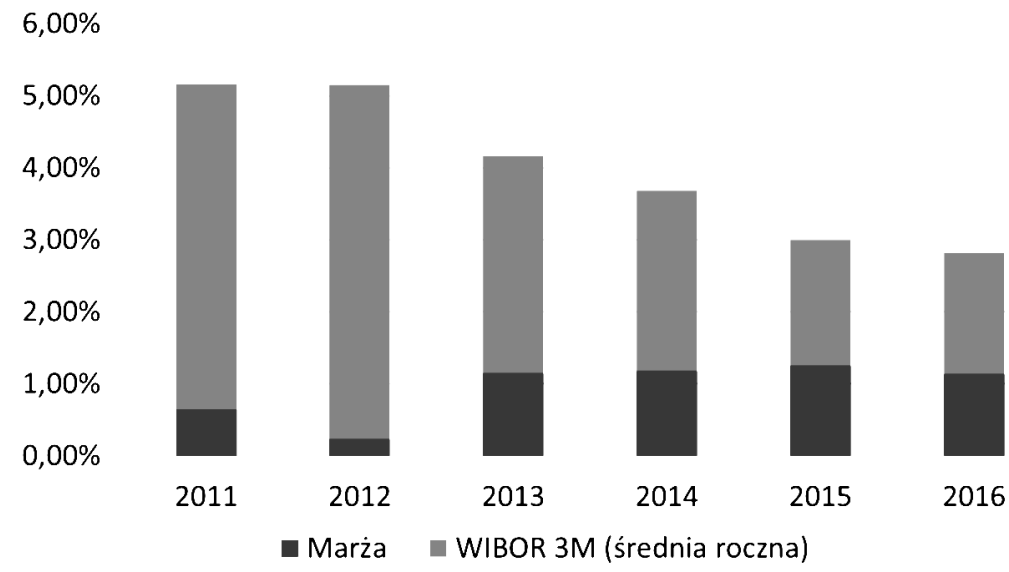

Rys. 3. Średnie oprocentowania zadłużenia (jako relacja wydatków na obsługę w roku $n$ do poziomu zadłużenia w roku $n-1$ dla JST w woj. lubelskim

Źródło: jak pod rys. 1.

ceny pieniądza w wielkości tego oprocentowania wyodrębniono wysokość WIBOR $3 \mathrm{M}$ (na podstawie którego jest zazwyczaj indeksowane oprocentowanie kredytów udzielanych jednostkom samorządowym) liczonego jako średnia arytmetyczna według stanu na ostatni dzień grudnia w każdym z analizowanych lat. Pozostałą część oszacowanego przeciętnego oprocentowania długu (po odjęciu stawki WIBOR 3M) określono jako tzw. marżę banków i instytucji finansowych (która odzwierciedla wszystkie dodatkowe koszty i prowizje związane z zaciąganymi zobowiązaniami 
dłużnymi). Z zaprezentowanych danych wynika, że wprawdzie poziom całkowitego oprocentowania długów dla JST z województwa lubelskiego w badanym okresie uległ zmniejszeniu, to jednak zasadniczy wpływ na ten spadek miało znaczące obniżenie rynkowych stóp procentowych. W tym samym czasie wzrosły marże bankowe, które obecnie przekraczają 1\%. Jest to zjawisko niepokojące, oznaczające, że instytucje finansowe wykorzystały opisywaną sytuację do zwiększenia swoich przychodów.

Analizując konsekwencje „,rolowania” długów samorządowych z punktu widzenia bezpieczeństwa finansowego, trzeba odnieść się także do potencjalnych skutków o charakterze długoterminowym, które mogą w przyszłości zagrozić stabilności finansowej sektora samorządowego.

Przede wszystkim w związku z wydłużaniem okresów, na które zaciągany jest dług, a także ze wzrostem marż kredytowych może dojść do znaczącego zwiększenia ogólnego poziomu długów samorządowych.

Po drugie, przy utrzymującej się niepewności na rynkach finansowych w przypadku wystąpienia nagłych zakłóceń zewnętrznych prowadzących do wzrostu rynkowych stóp procentowych sytuacja ta może zagrażać tym, iż wiele samorządów wpadnie w tzw. pułapkę zadłużeniową.

Po trzecie, zauważalne jest osłabienie funkcji ostrożnościowych IWZ, który przestaje być realną ochroną dla gospodarki finansowej JST, a staje się jedynie powodem do odsuwania potencjalnych trudności finansowych w czasie. Niestety, działanie to może powodować, że w przyszłości problemy te mogą wybuchnąć ze zdwojoną siłą

Po czwarte, operacje polegające na „rolowaniu” zadłużenia prowadzą do naruszenia reguły sprawiedliwości międzypokoleniowej, bowiem przyszłe pokolenia obciążone zostaną kosztami spłat długu zaciągniętego na finansowanie aktywów, z których w ogóle nie będą korzystały bądź też których okres użytkowania będzie w ich przypadku bardzo krótki. Zjawisko to jest szczególnie niebezpieczne wobec obserwowanych problemów demograficznych i wyludniania się wielu jednostek samorządowych.

Po piąte, refinansowanie zadłużenia pozwala także na nieuzasadnione odkładanie $\mathrm{w}$ czasie niezbędnych reform fiskalnych, co zagraża dalszą kumulacją problemów w przyszłości. Zamiast przeprowadzenia koniecznych cięć w wydatkach budżetowych, w tym również tych o charakterze inwestycyjnym, wiele samorządów, motywowanych głównie względami politycznymi czy chęcią wykorzystania środków europejskich, decyduje się na zaciąganie „nowych” długów na spłatę „,starych”, w efekcie zwiększając jeszcze poziom przyszłego obciążenia budżetu. Biorąc pod wagę to, iż wiele przedsięwzięć inwestycyjnych, w tym również tych realizowanych przy udziale funduszy unijnych, jest słabo ulokowanych w miejscowym kontekście społeczno-gospodarczym i naraża budżety samorządowe na dodatkowe nakłady związane z ich utrzymywaniem, sytuacja taka może sprzyjać zjawisku ,przeinwestowania" zagrażającemu przyszłej stabilności finansowej JST. 


\section{Zakończenie}

Z przeprowadzonych rozważań wynika, że „rolowanie” długów samorządowych, choć umożliwia wypełnienie obowiązujących reguł fiskalnych, w praktyce stwarza zagrożenia dla przyszłego bezpieczeństwa finansowego JST. Wiążą się one z towarzyszącym temu zjawisku nadmiernym wydłużaniem okresów spłaty zaciągniętych długów, jak również wzrostem kosztów finansowania zewnętrznego.

Zastanawiając się nad możliwymi kierunkami rozwiązania tego problemu, należy wyraźnie podkreślić, że wymaga ono ingerencji ustawodawcy, bowiem to przede wszystkim obowiązujące przepisy prawne, a zwłaszcza sama konstrukcja nowego limitu zadłużenia określonego w art. 243 u.o.f.p. były główną przyczyną jego powstania.

Nie odnosząc się jednak w tym miejscu do szeroko opisywanych w literaturze przedmiotu mankamentów IWZ, którego zmiana wymaga czasu oraz woli zarówno ze strony centrum państwa, jak i reprezentacji jednostek samorządowych, warto sformułować pewne wnioski, czy też postulaty, które należałoby rozważyć, poszukując już teraz pewnych sposobów wyjścia z zaistniałej sytuacji.

$\mathrm{Z}$ pewnością nie jest możliwe wprowadzenie całkowitego zakazu refinansowania długów przez JST, ponieważ prowadziłoby to do zbyt dużej ingerencji w ich samodzielność finansową i nadmiernego usztywnienia gospodarki finansowej. Byłoby także ukaraniem tych jednostek samorządowych, które efektywnie zarządzają swoim zadłużeniem, zastępując „stare” droższe długi „nowymi” tańszymi zobowiązaniami, i w efekcie doprowadzają do zmniejszenia kosztów ich obsługi.

Niewątpliwie pożądane jest wyłączenie jednorazowej spłaty wcześniejszego zadłużenia z IWZ. Warto zauważyć, że takie rozwiązanie zawierają propozycje zmian ustawy o finansach publicznych zgłoszone zarówno przez stronę rządową [Projekt z 11 kwietnia 2017], jak i samorządową, tj. Związek Miast Polskich [Projekt z 24 kwietnia 2017]. W propozycji rządowej uzależnia się takie wyłączenie od wykazania, że operacja ta obniża łączny koszt obsługi długu w całym okresie spłaty, z uwzględnieniem wartości bieżącej przepływów pieniężnych związanych $\mathrm{z}$ danym zobowiązaniem, przy czym określając te przepływy, należy wziąć pod uwagę wszystkie koszty, które jednostka jest obowiązana zapłacić. Ocenę taką będzie zobowiązana przeprowadzić Regionalna Izba Obrachunkowa, zaś JST zmuszona będzie do jej uwzględnienia. Z kolei propozycja samorządowa wyłącza spłatę „starego" długu z relacji określonej przez art. 243 u.o.f.p. bez żadnych dodatkowych warunków.

Dokonując oceny obu zaproponowanych rozwiązań ustawodawczych, należy wskazać, że propozycja Związku Miast Polskich nie odnosi się w ogóle do zasygnalizowanych problemów związanych z opisywanymi negatywnymi konsekwencjami „rolowania” długów. Projekt rządowy warunkuje zgodę na refinansowanie zadłużenia od wykazania ekonomicznej racjonalności takiej operacji. Choć w założeniach rozwiązanie to wydaje się słuszne, to jednak pewne wątpliwości dotyczą 
tego, czy w warunkach zmienności stóp procentowych i innych uwarunkowań rynkowych analiza taka może być w pełni wiarygodna. Obawy dotyczą również tego, czy instytucje finansowe nie zaproponują nowych sposobów ukrywania całkowitych rzeczywistych kosztów udzielanych kredytów (np. poprzez zawieranie w umowach kredytowych klauzul o możliwości zmiany poziomu marż kredytowych, czy też dalszego wydłużania okresu kredytowania, co może wpływać na efektywny wzrost tych kosztów).

W związku z powyższym wartą szczerszego przenalizowania propozycją rozwiązania tego problemu (zwłaszcza w kontekście jego długofalowych następstw) wydaje się postulowane m.in. w raportach NIK [2015 i 2016] przywrócenie zmodyfikowanego w stosunku do rozwiązań obowiązujących do końca 2013 r. ${ }^{10}$ limitu zadłużenia ogółem. Mógłby on być skonstruowany m.in. jako relacja zobowiązań ogółem do nadwyżki operacyjnej. Pozwoliłoby to wyeliminować główny mankament poprzedniego wskaźnika, jakim był brak nawiązania w jego konstrukcji do ekonomicznych kryteriów oceny bezpieczeństwa finansowego, odzwierciedlających indywidualny potencjał inwestycyjny oraz zdolność do obsługi zadłużenia przez poszczególne JST.

\section{Literatura}

Budzeń D., 2016, Refinansowanie dtugu lokalnego w Polsce, Studia BAS, nr 3(47).

Głuchowski J. (red.), 2001, Leksykon finansów, Polskie Wydawnictwo Ekonomiczne, Warszawa.

Gołębiowski G., Marchewka-Bartkowiak K. (red.), 2015, Leksykon budżetowy, Wydawnictwo Sejmowe, Warszawa.

Jurewicz D., 2016, Dlug samorządu - bodziec czy bariera absorpcji środków europejskich? Ruch Prawniczy, Ekonomiczny i Socjologiczny, zeszyt 2.

Kluza K., 2013, Wpływ zmian w ustawie o finansach publicznych na koszt finansowania samorzadów, Zarządzanie i Finanse, R. 11, nr 2, cz. 3.

KR RIO 2014, Zadhuzenie jednostek samorządu terytorialnego. Przestrzeganie ustawowych limitów zadtużenia i jego splaty, Krajowa Rada Regionalnych Izb Obrachunkowych, Łódź.

KR RIO 2016, Niestandardowe instrumenty finansowania potrzeb budzetowych jednostek samorzadu terytorialnego, Krajowa Rada Regionalnych Izb Obrachunkowych, Łódź.

Langer M., 2014, Ukryte formy zadtużenia jednostek samorządu terytorialnego - próba oceny zjawiska, Prawo Budżetowe Państwa i Samorządu, 4(2).

Marchewka-Bartkowiak K., 2012, Potrzeby pożyczkowe jednostek sektora finansów publicznych, Infos, Biuro Analiz Sejmowych, nr 17 (131).

NIK, 2015, Informacja o wynikach kontroli: Wykonywanie zadań Regionalnych Izb Obrachunkowych $w$ zakresie przeciwdziałania zagrożeniom wynikajacym z nadmiernego zadtużania się jednostek samorząu terytorialnego, Najwyższa Izba Kontroli, Warszawa.

NIK, 2016, Wptyw operacji finansowych stosowanych przez wybrane jednostki samorzadu terytorialnego na ich sytuację finansowa, Najwyższa Izba Kontroli, Warszawa.

${ }^{10}$ Określonego w art. 170 ust. 1 ustawy o finansach publicznych z 30 czerwca 2005 r. (Dz.U. z 2005, nr 249, poz. 2104) jako 60\% dochodów budżetowych. 
Projekt zmiany ustawy o finansach publicznych z dnia 11 kwietnia 2017 r. https://legislacja.rcl.gov.pl (22 maja 2017).

Projekt zmiany ustawy o finansach publicznych z dnia 24 kwietnia 2017 r. http://www.miasta.pl/ (22 maja 2017).

Rozporządzenie Ministra Finansów z 28 grudnia 2011 r. w sprawie szczegółowego sposobu klasyfikacji tytułów dłużnych zaliczanych do państwowego długu publicznego, Dz.U. nr 298, poz. 1767).

Ustawa o zmianie ustawy o finansach publicznych oraz niektórych innych ustaw z dnia 8 listopada 2013 r., Dz.U. z 2013, poz. 1646.

Ustawa z dnia 23 kwietnia 1964 r. - Kodeks cywilny, Dz.U. nr 16, poz. 93 ze zmianami.

Ustawa z dnia 29 sierpnia 2009 r. o finansach publicznych, Dz.U. nr 157, poz. 1240 z późn. zm.

Witalec W., 2014, Kredyt konsolidacyjny w gospodarce finansowej samorządu terytorialnego, Finanse Komunalne, nr 7-8.

Woźniak M., 2014, Analiza sytuacji finansowej JST w oparciu o dane sprawozdawczości budżetowej i finansowej - wolne środki, [w:] Walczak P. (red.), Zadtużenie jednostek samorządu terytorialnego, $\mathrm{CH}$ Beck, Warszawa. 